\title{
Die gewonde God: 'n Teologies-etiese besinning, veral vanuit Khoisan-perspektief
}

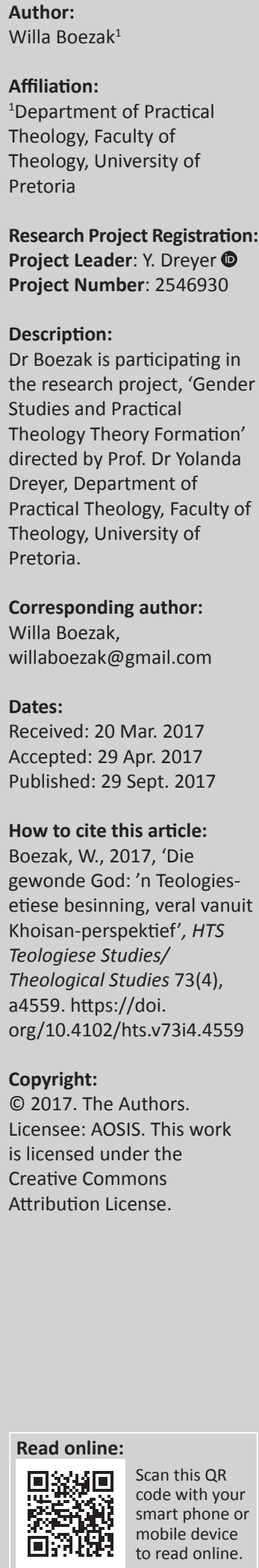

This article presupposes the right of the faithful to pose critical questions about God. Godconcepts cannot be distanced or freed from ideology. In the Hebrew Scriptures, the reflection on Jahwe and Elohim are mostly influenced by Israel's exodus experience. The liberating God becomes a theme that legitimises their faith, but is ultimately coloured by their patrarchal Sitz im Leben. For black theologians, the image of God as the Liberator stands foremost as the Crucified. This has clear connections with Western thinking such as that of Jürgen Moltmann. The ancient native people of southern Africa developed a consciousness regarding a Higher Being through many years, eventually integrating it into their holistic worldview. God's involvement in human suffering plays a significant role in all of these expressions of faith. The different views of God as the transcendant, yet involved God, should be revisited within the context of our current society characterised by human suffering, chronic poor communities, gaping inequality and increasing corruption. The theological-ethical question is whether the Khoisan people's view of a wounded God is more suitable to help faithful people to engage with the world in a meaningful way.

Hoekom is dit so dat ons vervolg en verdruk word deur die Christene? Is dit omdat ons in die woestyn lewe, klere aantrek wat van velle gemaak is, sprinkane en wilde heuning eet? Maar - was Johannes die Doper dan nie 'n Boesman nie? Het hy nie in die woestyn gebly nie? Het hy dan nie dieselfde velklere gedra soos ons nie? Het hy nie sprinkane en wilde heuning, soos ons, geëet nie? So - was hý nie 'n Boesman nie?

Anoniem

\section{Inleiding}

Vir die meeste gelowiges in alle geloofsgemeenskappe is die gedagte aan iets soos die kwesbaarheid of verwonding van 'n almagtige God waarskynlik totaal onaanvaarbaar. Durand (1976:12-15) gee 'n uitstekende oorsig van die vroeg-Christelike denke en hoe die Apologete gepoog het om die Christenheid te helleniseer ('Alle klem val op God as die transendente Syn, op sy selfgenoegsaamheid, onveranderlikheid en ewigheid') in sy publikasie Die lewende God. Hier word die dogmahistoriese kritiek van Adolf von Harnack spesifiek vermeld asook filosowe soos Plato en Aristoteles. Teologies-eties word die voor-Christelike Grieks-filosofiese ideaal eintlik eers by die Stoa duidelik: Omdat God vir hulle die affeklose, apatiese Syn is, moet ook die mens daarna streef om 'n staat van apátheia te bereik (Durand 1976:13). Dat God egter in Jesus Christus geopenbaar word - nie as die metafisiese Onbeweeglike nie - maar as die Gekruisigde, is deeglik deur Jürgen Moltmann (1973) in sy Der Gekreuzigte Gott verwoord. In hierdie artikel word die teodisee-vraagstuk binne persoonlike sowel as sosiale etiek herbekyk-veral soos dit deur die Khoisan aan die orde gestel word.

\section{Die gekruisigde God}

Moltmann (1973:294-317) is van mening dat indien ons wil probeer om uit die teologie van die kruis konsekwensies vir die politiek te trek, ons nie net kan volstaan met abstrakte verhoudingsbepalinge van kerk en staat of van dogmatiese geloof en politieke handelinge nie. Daar moet konkreet op die religieuse probleem van die politiek sowel as op wette en dwangmatighede ingegaan word waardeur menslike lewe ekonomies gestrem, beklem of onmoontlik gemaak word. Ons vryheid van geloof word in 'n politieke, vrye ruimte beleef. Daarom dwing die vryheid van geloof gelowiges tot bevrydende aksies, omdat hulle juis deur hierdie vryheid bewus word van die situatiewe lyding van uitbuiting, vervreemding en onvryheid.

Die situasie van die gekruisigde God maak menslike situasies van onvryheid sigbaar as 'duiwelskringe' wat deurgebreek moet word. Politieke hermeneutiek reflekteer die nuwe situasie 
van God in die onmenslike situasies van die mens. Dit negeer die magsverhoudinge wat mense onmondig maak en bewerk die ontplooiing van hulle menslikheid. Daarom kom dit tot kritiese solidariteit met ander vryheidsuitinge. Politieke hermeneutiek is geen redusering van die teologie nie, maar die interpretasie daarvan reik tot op politieke vlak. 'Sie fragt nicht nur, welchen Sinn es habe, von Gott zu reden, sondern auch, in welcher Wirkung es geschieht' (Moltmann 1973:294).

Moltmann (1973:301) reken dat die memoria passionis et resurrectionis Christi bevrydend sowel as gevaarlik is. Die Christelike teologie het die geskiedenis nog altyd soteriologies uitgelê, terwyl 'n teologiese herinterpretasie van die politieke dimensies van Jesus se kruisiging en opwekking ontbreek. Die dood van Christus was ook die dood van 'n politieke misdadiger - 'n ontering en skandvlek. Wanneer hierdie Gekruisigde egter opgewek en tot Christus verhoog word, verander wat volgens die algemene opvatting die laagste sou wees, na die hoogste. Die heerskappy en koninkryk van God word dan nie meer weerkaats in politieke heerskappy en wêreldryke nie, maar deur die diens van hierdie Christus wat aan die kruis tot die dood verneder is. Die gekruisigde God is geen apolitiese Opperwese nie, maar inderdaad die God van die armes, onderdruktes en vernederdes. Die heerskappy van die politiek-gekruisigde Christus kan slegs verbrei word deur die bevryding van magsvorme wat mense verslaaf en apaties maak, en van die politieke godsdiens waardeur dit gestabiliseer word. In hierdie bevrydingsproses van mense is God se teenwoordigheid reëel:

Die Realpräsenzen Gottes bekomen damit den Charakter der praesentia explosiva. Bruderschaft Christi (sic) bedeutet leidende und active Teilnahme an der Geschichte dieses Gottes. Ihr Kriterium ist die Geschichte des gekreuzigten und auferweckten Christus. Ihre Kraft ist der seufzende und befreiende Geist Gottes. Ihre Vollendung liegt im alles befreienden und mit Sinn erfüllenden Reich des dreienigen Gottes. (Moltmann 1973:315)

\section{Swart politieke prediking en besinnings}

In die sewentiger en tagtiger jare van die vorige eeu het SuidAfrikaanse teoloë soos onder meer Mpho Ntoane, Desmond Tutu, Zacharias Mokgoebo, Sam Abrahams, Zaphania Kameeta, Bongojalo Goba, Manas Buthelezi, Chris Loff, Hannes Adonis, Simon Maimela, Daan Cloete, Takatso Mofokeng, Welile Masamiza, Shaun Govender en Allan Boesak voortdurend met die voorstelling van 'n lydende God geworstel. Die stukrag vir swart politieke prediking voor 1994 was vanweë die versugting om 'n nuwe, mensliker bedeling. Dog, te midde van neo-koloniale onderdrukking, was 'n swart Messiaanse verwagting van die omverwerping van die regime vir sommiges aantrekliker as die idee van 'n kwesbare, gekruisigde God.

Net na die Soweto-opstande is 'n preek van Kameeta (1976:14) gepubliseer met 'My God, my God, waarom het U my verlaat?' as teks (Matt 27:46). Sy uitleg neem 'n aanvang met die stelling dat gelowiges en 'die wêreld' die dood en lyding van Jesus verskillend interpreteer. Vir die wêreld, poneer die prediker, was dit duidelik dat die sterwende Messias 'n bedrieër, godslasteraar en ' $n$ bedreiging vir die wet en orde van die samelewing was. Sy uitroep van verlatenheid was dus uit die oogpunt van die maghebbers 'n erkenning van 'defeat and despair' (Kameeta 1976:14). Kameeta (1976) beklemtoon egter dat Jesus se lyding nie 'n doel op sigself was nie, maar die bevryding van die hele skepping en die verwerkliking van God se heerskappy in hierdie wëreld. Dit noem hy die 'rewolusie van die kruis'.

Manas Buthelezi (1977:8) stel sy standpunt oor 'politieke prediking' in daardie tydgleuf. 'n Voorbeeld hiervan was sy preek Service to the down-trodden op 12 Desember 1976, gebaseer op Matteus 25:31-46. God se menswording het ingehou dat hy bespot, gearresteer, geslaan, gegesel en vermoor is. Iets is ernstigs verkeerd wanneer die kerk dit kan bekostig om in gerief en weelde te leef, en sosiale en politieke aansien te geniet, terwyl 'n groot deel van haar lidmate daagliks leed en lyding moet verduur. Die Bybelse imperatief van diensbetoon moet dus veel breër opgeneem word. Ware diens aan God geskied binne die raamwerk van dienswerk aan ander - veral aan die vertraptes en onbelangrikes. Buthelezi (1977) skryf soos volg:

The gospel should be defined and preached in such a way that it makes sense to the reality of suffering and unrealised aspirations, which is the lot of so many people in our churches. (p. 8)

Dit was egter eers in sy latere Violence and the cross in South Africa today (Buthelezi 1979:55-57) dat hy dieper op die verband tussen God en lyding ingaan. Die kruis van Christus is geen simbool van kosmetiese romantiek nie, maar ' $n$ instrument van geweld. Die Nuwe Testament is egter nie geïnteresseerd in die kruisigingsgeweld as sodanig nie, maar in die feit dat dit aanduidend is van die maat van Gods liefde. Buthelezi (1979) beweer dat

On the cross God's love went through the test of the infliction of violence ... It is not the violence of the cross that saved us, but the love of God that endured it. (p. 55)

Buthelezi onderskei dan tussen onderdrukkende en bevrydende lyding. God het die ervaring van lyding - wat die gevolg van ongeprovokeerde geweld was - omvorm tot 'n instrument van bevryding. Op grond van die feit dat Christus se kruis ' $a$ step beyond words' (Buthelezi 1979:57) was, is die bevrydende lyding van mense insgelyks kragtig 'beyond words'. Hy dink spesifiek aan mense wat in selfopoffering bereid was om plaasvervangend te ly. Hulle lewe was één lang Goeie Vrydag '... because they dared to live a vicarious life of championing the interests of their fellowmen' [sic] (Buthelezi 1979:57). Byna onwillekeurig dink 'n mens aan iemand soos wyle Nelson Rolihlahla Mandela.

Vir Maimela (1982:59) kan 'n gesprek oor God en lyding slegs plaasvind indien ons die politieke konteks in ag geneem word, te wete die konkrete wêreld van konflik. Die God van die eksodus, die profete en die Messias openbaar Hom- of Haarself as Iemand wat uitgeworpenes en veragtes se kant kies. Juis omdat God te midde van 'the struggling poor' (Maimela 1982:59) te vinde is, noodsaak dit 'n nuwe 
hermeneutiese invalshoek, naamlik die 'voorkeurreg vir die onderdruktes' (preferential option for the oppressed). Die smeekgebede en credo van die lydendes word deur God se heilsdade in die geskiedenis gelegitimeer: 'God suffers in order to break all chains which have subjected them to spiritual and physical bondage' (Maimela 1982:59).

Moltmann se invloed kan in Mofokeng (1983:36-263) se sistematies-teologiese benadering bespeur word. Christologies gesien, word die kruisgebeure in die geskiedenis van die 'trinitariese proses' van God opgeneem sodat Sy of Hy inderdaad in die armes is. Andersyds bly God transendent. Die werklikheid van die medelydende, strydende God se teenwoordigheid in die lydende gemeenskap is egter nie vanselfsprekend ten aansien van die skynbaar paradoksale, goddelike afwesigheid nie. Dit is 'n belydenis van geloof. Dit gaan vir Mofokeng (1983) om die stryd om menslikheid, bevrydende selfontdekking en waardigheid:

In other words, with his cry on the cross, He raises new followers. $\mathrm{He}$ also calls his followers who had abandoned him at his decisive hour, the poor, the sick and the sinners and the disciples who had distanced themselves from him or fled from him, to follow him to the very end, even the end of the cross. He calls them to take that ultimate action, like him, to endure torturing and crucifixion for justice. (p. 263)

Ek is van mening dat daar by swart teologie veel meer klem op die moreel-etiese implikasies van Godsbeskouinge gelê word as op dogmatiese of filosofiese nadenke. God is nie skuldig aan die 'human crying of oppression' nie, beklemtoon Goba (1982:53). So 'n uitgangspunt val natuurlik binne die denkraamwerk van die teodisee-vraagstuk: Kan 'n regverdige, liefdevolle Skepper of hemelse Vader verantwoordelik gehou word vir die ongelukkigheid en kwaad in die wêreld? Daarom is dit vir hom misleidend om van die sonde in algemene terme te praat: 'For sin is a product of negative human intentions expressed in socio-political structures' (Goba 1982:53). Binne die lydende gemeenskap moet die oeroue Afrika-waarde van koöperatiewe patos herontdek word. In teenstelling met die 'westerse tendens van individualisme', reken hy, moet koöperatiewe persoonlikheid - ubuntu - die basis wees vir die skepping van 'n dinamiese, meelewende gemeenskap. Die aanvaarding van medeverantwoordelikheid (Ziva ngamvunye) en groepsgees of om-te-behoort-aan (Okwakho shwami) is onontbeerlik vir die stryd teen oorheersing, onderdrukking en ekonomiese uitbuiting (Goba 1973:67). Sy opvattinge oor 'korporatiewe persoonlikheid' verskyn in die eerste bundel opstelle oor swart teologie wat in Suid-Afrika in die 1970s gepubliseer en byna onmiddellik daarna verban is. Goba (1973) gee die volgende te kenne:

What is the significance of this concept of corporate personality for us in South Africa today? What we discover in the concept as it manifests itself in Israel and Africa is this unique idea of solidarity, a social consciousness that rejects and transcends individualism. Apart from this, one discovers a unique sense of a dynamic community, a caring concern that seeks to embrace all, a love that suffers selflessly for others. In this country many of us black people have allowed ourselves to be victims of individualism and capitalism. We are no longer living as a dynamic community; we have lost so much of our sense of corporate personality. Influenced by capitalism we have become materialistically self-centred, and the emphasis seems to be on individual enterprise and material acquisition for the individual - not for the black masses. Poverty is raging and swallowing many of our people, but the few among our black élite who have means are not bothered that thousands of blacks go to bed with empty stomachs. (pp. 68-69)

Bovermelde waarneming geld vandag veel meer as in die 1970s. Goba (1979:12) het voortborduur op sy tema van meelewing soos ' $n$ latere artikel aantoon. God wil mense van persoonlike en maatskaplike gebrokenheid bevry. Trouens, aan die bevrydende teenwoordigheid van Christus mag nie getwyfel word nie, omdat geloofsenkelinge sowel as -gemeenskappe in staat gestel word om die teenwoordigheid van die koninkryk van God konkreet te ervaar. Dit is shalōm geïnkarneer in persone en menslike institusies (Goba 1979:12).

Desmond Mpilo Tutu is 'n buitengewoon begaafde orator. Sy uitsonderlike persoonlikheid vind neerslag deur middel van wisselende emosies van erns en humor wat kenmerkend aan hom is. Die leser ervaar iets van hierdie rare kombinasie in sy 'Jesus Christ - the Man for Others' (Tutu 1982):

We could not accuse our Lord of using religion as a form of escapism from the harsh realities of life, as most people live and experience it. The jibe of the Marxist could not apply to him - he never used religion as an opiate of the people, promising them 'pie in the sky when you die'. He knew that people want their pie here and now. And not in some future tomorrow. A post-mortem pie is an oddity in any case. (p. 28)

Sy preek eindig met die versekering dat ons geloof in die geskiedenis van die lydende Christus gegrond is. Hy het egter sy lyding oorwin en maak aan ons, sy volgelinge, dieselfde mag beskikbaar.

In twee van Allan Boesak se preekbundels, Die vinger van God (1979) en Walking on thorns (1984) word die problematiek van die feitelike ervaring van swart mense telkens aan die orde gestel. So word byvoorbeeld in die hoofstuk getiteld Jesus en Pilatus (Boesak 1979:24-28), na aanleiding van die lydensgeskiedenis (Joh 18:37; 19:4, 15), verklaar dat die 'godlose, demoniese staat ten slotte aan God verantwoording verskuldig is'. 'n Ontduiking hiervan is uitgesluit (Boesak 1979):

Wanneer die situasie so helder en onmiskenbaar is soos hier by ons, en wanneer die geroep van die armes en die ellendiges dag na dag tot God opstyg, en die onreg daar is vir almal om te sien, is dit onvergeeflik dat Christene neutraal wil staan en dit blykbaar onmoontlik vind om onomwonde aan die kant van reg en geregtigheid uit te kom. (bl. 28)

In 'n Paassondag-boodskap beklemtoon die prediker (Boesak 1979) dat die opstanding van Jesus Gód se opstand is:

\footnotetext{
... teen siekte en lyding en dood. Sy opstand teen die ellende wat ons in die dag bekruip en in die nag ons bang maak: ons armoede, ons magteloosheid teen die magte en die wanhoop wat ons geloof ondermyn. Die opstanding van Jesus is God se opstand teen die uitholling van ons menswees ... (bl. 49)
} 
Boesak (1979:63-67) kom in die preek getiteld 'Die oog van die naald' tot die slotsom dat die koninkryk van God 'n omgekeerde orde is:

Die Messias maak duidelik dat sy Ryk nie bedoel is vir die vernames, die rykes, die status-mense en die magtiges nie, nee, dit is juis andersom! Hy laat sien dat die koninkryk van God bestem is vir die nietiges, die veragtes, die geringes. (bl. 65)

In die tweede bundel, Walking on thorns (Nederlandse vertaling, Kiest dan Heden, Wie Gij Dienen Zult - Boesak 1984b:22-41), doen hy 'n beroep op die kerk tot groter betrokkenheid: 'Hoe kunnen wij de pijn, het bloed, de wreedheid van dit system aanzien en niet kiezen voor gerechtigheid, vrede en menselijke vrijheid?' (Boesak 1984b:22). Die verhaal van Daniël (Dan 3:17, 18) word as uitsonderlik aangeteken omdat God, in hemelse solidariteit, sáám met mense 'de brandende vuuroven' (Boesak 1984b:22) ingegaan het. Die vreugde van die gehoorsame kind van God lê dus nie in die feit dat die risiko uitgeskakel word of die beproewing buite werking gestel word nie. Die vreugde is die ontdekking dat hierdie God '... met je mee wil lijden' (Boesak 1984b:22). Die slotwoord van Boesak (1984b:41) se preek is tegelyk die kerngedagte:

Gods tegenwoordigheid te midden van pijn en verschrikking en de dreiging van de dood is niet een tegenwoordigheid die bevestigt of sust ... Het is de tegenwoordigheid, die het lijden voor wettig verklaart, maar ertegen protesteert. (bl. 39-41)

Insgelyks word In Black and reformed (Boesak 1984a:62-69) die noodvraag van die profeet 'Hoe lank, o Here?' (Hab 1:1-4) vertolk as '... a cry of deep anguish and endless pain'.

Die kwessie van God se oënskynlike onbetrokkenheid kom ook ter sprake en wel in 'n preek oor Psalm 42:3, getiteld 'God as vraag' (Boesak 1979:29-33). Die subtitel 'Geloof, twyfel, onsekerheid, en hoop' is alreeds treffend. Dit begin met die skreiende vraag van 'n swart Amerikaanse biskop uit die negentiende eeu: 'Is daar dan geen God nie?' (Boesak 1979:29). In sy lewe het hy 'n verlatenheid ervaar dat '... God nie meer is nie'. Soos die Psalmis soek hy ook naarstiglik na God. Die prediker wys voorts daarop dat op die gelowige se angstige vraag: 'Waar is God?' (Boesak 1979:30) op 'n spottende manier deur 'die wêreld' gereageer word. Die probleem is dat geloof, veral vanuit die die 'soewereine mens' se oogpunt, onaanwysbaar is. Is God überhaupt nog werklik vir mense? Hoe belewe mense God vandag? Trouens, vir die lydendes skyn dit asof God Hom of Haar by alle onwaarhede en mites neerlê en dat Hy of Sy ook 'sonder enige protes aan die kant van die maghebber' staan. Dan gee Boesak 'n opvallende wending aan sy boodskap. Die fundamentele verskil tussen Jahwe en die afgode is juis dat die Bybel 'n lewende God openbaar. Daarom moet die gemeente, in plaas van om aan wanhoop toe te gee, in die wêreld en in die geskiedenis lewe met hierdie geloof in God. Op grond van 1 Petrus 1:21 postuleer hy dan die identiteit van geloof op ' $n$ bepaalde moment ten aansien van die skynbare afwesigheid van God. Geloof sien dat die Christen geen 'emigrant uit die geskiedenis' kan wees nie. Dalk bestaan die ervaring van God se werklikheid alleen in die bereidheid '... om ons te laat opneem in die stryd vir God en sy Ryk, in die geskiedenis en in hierdie betrokkenheid ... kan ons gestalte gee aan onse geloof wat tewens hoop is op God' (Boesak 1979:32-33).

Dit ly geen twyfel nie dat swart politieke prediking in die apartheidsera menige gelowige tot bevrydende, geweldlose protesaksie opgeroep het.

\section{Bruin protesliteratuur}

Die tema van die afwesige God het dikwels in straatteaters, protesliedere en -poësie te berde gekom soos byvoorbeeld in 'Bede' van Petersen (1979:2):
Laat dit dan wees, O Heer, dat ek
'n Duisend jaar gelee teen God
En mens gesondig het ...
Dan weet ek nou, op U bevel
Is hierdie skurfte blootgestel:
In watter dieptes
En met verrotte slym besmeer
Het ek nie daar versleg,
Dat selfs U, Heer, van my moes wyk ...
My nie wou reinig van die slyk?
Laat my dan maar soos Lasarus
Tevrede wees, met streling van
Elk honger honde-tong;
Dan weet ek tog, dis U besluit,
Die vloekstraf van 'n donker huid.
As dit $\mathrm{U}$ straf is, dat ek so
Moet ly, dan wil ek swyg, O Heer;
Leer my berusting dan;
Laat my dan maar my kruisweg gaan,

Tot waar ek voor die donker staan ...

As 'n skepping uit 1944 is die bostaande gedig van buitengewone historiese belang, omdat dit die eerste amptelike Afrikaanse versetliteratuur van die ondergesteldes is wat verskyn het. Destyds het Malherbe (1948:339) geweier om Petersen se cri de coeur as poësie te erken, daar sy passie kwansuis 'te rou' sou wees. In 'Bede' kom die leser wel onder die indruk van die intense bitterheid van die digter. In ' $n$ tydperk van steeds toenemende rassisme in 'n land waar die beleid, geskoei op 'n pigmentokrasie, onafwendbaar gelyk het, word na die afwesigheid van God verwys: 'dat selfs U, Heer, van my moes wyk ...' Sy wrange ironie word egter juis in sy skynbare berusting sigbaar. Hy aanvaar God se raadsbesluit dat hy 'n 'Duisend jaar gelee teen God en mens gesondig het ...'; as 'n 'kind van Gam' met 'die vloekstraf van 'n donker huid' getref word. Hier was egter geen apatiese aanvaarding van die status quo nie, maar juis 'n verwerping daarvan. Vernon February (1981:81) merk in sy waardebepaling van Petersen se poësie tereg op dat die digter se sosio-realisme nie 'n weerspieëling van die politieke 
radikalisme van die bruin mense van daardie tydperk was nie: 'There is no indication that this bitterness was used to propagate revolutionary change or encourage political consciousness among the coloureds.' Petersen was eerder '... the loner, the romantic who suffers in silence'.

Toe Adam Small, filosoof en woordkunstenaar, in die Kaapse patois van bruin Wes-Kapenaars begin dig het, was dit uiters riskant omdat Afrikaner-taalpuriste en separatiste dit as verdere bewys van hulle andersoortigheid wat apartheid noodsaak, kon gebruik. Nogtans het Small geweier om sy satires te laat vasvang deur bepaalde ideologiese kriteria en inderdaad is hy van hierdie genre die eksponent par excellence. Die literêre kritikus Vernon February (1981), wys daarop dat vele gedigte van Small satiriese steekhoue na religie was - vulgêre aanvalle op die konserwatiewe en selfs rassistiese rol wat die Christelike kerk in die apartheidssamelewing gespeel het:

Small is capable of ironic depiction, of inverting the Christian myth, of using the vulgar argot, which by sheer contrast with the original Biblical passage and elevated language, irritates. But Small is by no way anti-clerical in the négritude vein. His products are not vituperative ejaculations of hatred. (p. 106)

Ons beperk ons hier by gedigte uit sy bundel, Kitaar my kruis, gepubliseer in 1974. In die onderstaande vers (Small 1974:33-

34) word die situasie soms as ' $n$ beslissing van God gesien:

die Here het gaskommel

en die dice het verkeerd gaval vi' ons

daai's ma al ...

daar's mos kinners van Gam en daar's kinners van Kain

so dis allright pêllie

ons moenie worrie nie.

'n Element van aanvaarding tree na vore in die vers 'Lydensweg' (Small 2011:27-28). Meer waarskynlik is dit 'n sinspeling op Jesus se uiteindelike aanvaarding van sy eie lydensweg:

Here djy kan maar lyster
na ons lied
sonder worrie, ons is lankal
verby vadriet ...
so moenie worrie Here
ek is opgafix
ek is my eie Here
en dan's ons twie kiets
o al lankal in plekke
soes Windermere
het ons al ons verlangens
afgaleer

Treffend is dat die digter in die lyding van sy mense 'n weerspieëling van die lyding en vernedering van Jesus self sien. Op byna familiêre wyse tree Small (2011:28-32) in gesprek met God in die 'Groot Krismisgabet' en word die stal van Betlehem ' $n$ metafoor vir die lewe in krotbuurte en townships: ons ken sulke plekke Here

dja ons ken hulle

ons het duplicates van hulle allover

in die Windermere

in die Distrik Ses

in die Blouvlei ...

Small is dus nooit anti-Christelik nie. Wat hom kennelik pla, is die pervertering van die Christelike geloof. In 'n bydrae tot Moore (1975:38) se bundel, Zwarte Theologie in Zuid-Afrika spreek hy die wens uit dat '... we in onszelf een einde kunnen maken aan de belachelijke gelijkstelling van blank en waardevol'. Moontlik is die sielvolste uitdrukking van die patos van hierdie enigmatiese sestiger, die strofe uit sy Die eerste steen? (Small 1961:7):

en Heer

Laat ons vernedering

nou die vuurproef van ons liefde word

Adam Small is eers in 2012 - 50 jaar na die verskyning van sy bekroonde Kanna hy kô hystoe - met die gesogte Hertzogprys vereer. In 'n onlangse bundel essays wat aan hom opgedra is (Carstens \& Le Cordeur 2016), skryf Nico Koopman:

Small het tydens die apartheidsjare Afrikaans gebruik wat SuidAfrika help transformeer het, weg van apartheid, ontmensliking, vyandskap, onreg en verdrukking, in die rigting van demokrasie, menswaardigheid, helende versoening, geregtigheid en vryheid. (bl. 540)

\section{Jahwe is 'n Kryger}

Seker die mees radikale uitspraak ten opsigte van die soeke na en geloof in ' $n$ lewende, handelende God, word in Eksodus 15:3 verwoord: 'Die HERE is 'n krygsman.' (1933-vertaling) Dit word myns insiens verkeerdelik in die 1983-vertaling versag tot 'Die Here is oorwinnaar in die stryd.' Die daaropvolgende vers weerspreek enige poging tot eufemisme: 'Die strydwaens van die farao en ook sy leer het Hy in die see geslinger.'

Van Zyl (1975:145) stel dat uit die hele Eksodus-verhaal dit telkens blyk dat God vir sy of haar volk stry en skrik en verwarring onder die vyande teweegbring. Daarom roep hulle in dieselfde oorwinningslied uit: ' $U$ hand verpletter die vyand' (Eks 15:6). Jahwe is dus sonder enige twyfel die Verlosser van Israel en wel in militêre sin (Eks 14:30). Tot en met die tyd van Moses het die volk onder 'n suiwer teokrasie geleef. In daardie tyd was God die Een wat saam met die volk gaan, wat die geskiedenis laat gebeur en daarin ingryp. God is nie 'n staties-passiewe Syn wat sommer net is en niks aan die lydende situasie kan doen nie; trouens, Jahwe is die aktief-werkende, die geskiedenismakende, die mee-trekkende, die verlossing-bewerkende. Aan die ander kant, meen Van Zyl (1975), is die farao ook deur sy onderdane as ' $n$ god beskou en staan hy en die talle ander Egiptiese gode as 't ware teenoor Jahwe in 'n reële stryd gewikkel: 
Dit is nie 'n vae denkbeeldige mitologiese godestryd nie, maar ' $n$ egte stryd in die geskiedenis en die weergawe van die geskiedkundige stryd is op so 'n manier aangeteken dat die getuienis, die blywende boodskap, op die voorgrond staan. (bl. 171)

Dus, hoewel die Wes-Europese konteks van teoloë soos Moltmann heeltemal van die Suid-Afrikaanse konteks verskil het, het hulle besinninge oor 'n lydende God merkwaardig in terme van die moreel-etiese reikwydte daarvan ooreengekom. Dis des te meer merkwaardig hoeveel raakpunte daar tussen die vermelde sieninge en die oergeloof van die Khoisan van Suid-Afrika bestaan - ondanks die tydsgaping en beduidende kultuurverskille.

\section{Moeder Aarde}

Die Khoisan se benadering tot godsdiens en kultuur is ' $n$ holistiese een. As dit sistematies was, sou ons selfs van 'n 'groen teologie' kon praat. Oor letterlik derduisende jare heen het hulle 'n geïntegreerde lewensstyl gekweek wat deur sosio-religieuse waardes onderskraag is. In 'n bepaalde sin is dit daarom kunsmatig om hulle oergeloof en kultuur as afsonderlike silo's te bespreek. Soos Krüger (1995:219-220) dit stel: '... their religion was inseparable from their sociocultural existence as a whole, without any trace of the modern Western distinction between "sacred" and "profane". . Met ander woorde, onmiddellike, moreel-etiese imperatiewe is aan hulle godsbegrip verbind. In my boek, Só glo ons (Boezak 2016:257282), word vertel hoedat die opeenvolgende Christelikgedrewe koloniale en neo-koloniale aanslae veel van hulle oorspronklike geloofstrukture laat wegkalwe het totdat slegs sekere aspekte daarvan behoue gebly het. Spore hiervan vind ons vandag by twee Khoisan onafhanklike kerke, naamlik, die Griekwa Independente Kerk en die Nama Qua Kerk van Port Nolloth.

Colin Bundy (1988:8-10) wys daarop dat dit argeoloë was wat die mite van 'leë lande' as vals blootgelê het. Die terra nullius idee is gebruik as 'n morele regverdiging vir koloniale invalle en die eerste mense wat dit moes afweer of absorbeer aan die suidpunt van Afrika, was die Khoisan. Dit was die Portugese, wat daarna gehunker het om die wêreld buite Europa te ontdek, wat die Kaap in 1488 bereik het. $\mathrm{Na}$ oorlewing in stormagtige waters, het hulle dit Cabo Tormentuoso genoem. Bredekamp (1986:102) skets die tweeslagtige aard van Bartolomeus Diaz se prestasie: 'It marked the beginning of a new era of exploration and trade, but for the indigenous Khoikhoi and San it was the beginning of a process of colonial subjugation.' Hulle uiteenlopende wêreldbeskouinge het groot konflik veroorsaak wat selfs tot bloedvergieting gelei het. Terwyl die inboorlinge grond wat nie vervreem kon word of privaat aan enigeen, insluitend die leierskap kon behoort nie, as 'n gawe van God beskou het, was dit vir die Europeërs bloot 'n kommoditeit. Khoikhwe [stamhoofde] kon hulle gebiede slegs ten behoewe van hulle mense as vruggebruik bestuur en selfs 'n khoibaha [opperhoof] kon nie grond verkoop nie. Trouens, die ondertekening van verdrae met Europese trekboere of die koloniale regering het nie die reg tot eienaarskap ingesluit nie. Dit het mettertyd gruwelike misverstande veroorsaak. Grond en die verlies daarvan was sonder twyfel die hoofoorsaak van die bloedige konflikte met die vreemdelinge (Marks 1972:55). Krüger (1995:225) beskryf dit as '... a brutal clash between apparently irreconcilable cultures'.

Moeder Aarde, is geglo, behoort aan die Opperwese. Dit hou verdere sakrale betekenis in omdat gereelde aanbiddingsrituele daaraan verbind is, waar pasgebore babas se naelstringe begrawe is en waarheen afgestorwenes teruggeneem moes word. Na jare se onderhandelinge tussen die Suid-Afrikaanse en Franse regerings, is Sara Baartman se oorskot in 2001 uit Parys teruggebring. 'n Verdere oorweging rakende haar staatsbegrafnis was waar sy begrawe moes word. Die deurslaggewende faktor was die feit dat haar naelstring naby Hankey in die Oos-Kaap begrawe is (Boezak 2016:216-256). Khoisan-Afrikane het aldeur 'n kosmologie ontwikkel wat die harmonie tussen alle lewende wesens bevorder het. Hulle het na aan die natuur sowel as aan die Skepper as die Gewer van reën, gesondheid en oorvloed geleef. Kolonialisme het daardie sakrale band verbreek. Dit gaan dus om veel meer as net die verlies aan grond en lewensmiddele.

Emile Boonzaier et al. (2000:57) meen dat 'Western historians in the 1800s unashamedly ... justified the right of certain nations to conquer, rule and actively transform those 'others' whom they branded as inferior to themselves.' Die Afro-Amerikaanse filosoof, Cornel West (1982:57), toon aan dat dit met die Europeërs se 'normatiewe blik' te make gehad het. Deur skynwetenskappe soos frenologie en fisionomie is die fondasie vir die Eurosentriese beginsel van negatiewe vergelyking reeds in die sestiende eeu gelê. Kieskamp (1998:163-170) redeneer dat 'n 'lewensketting' geskep is: God heel bo, dan mense, gevolg deur die diere. Op verskeie lyste is die Khoisan op die laagste ry van menswees geplaas nader aan ape en sonder 'n siel. Hierdie Eurosentriese beginsel het beteken dat wanneer daar met 'n normatiewe blik na Suid-Afrika se eerste inheemse mense gekyk is, hulle blykbaar elke bepalende kriterium gemis het vir'n beskawing: 'n koning, 'n regstelsel, wette, geskrifte, die kunste, landbou, geld, huwelike en godsdiens. Dat hierdie 'aanwysers vir beskaafdheid' wel tot 'n oormaat by die Khoisan bestaan het, is in die klassieke werk van Isaac Schapera, The Khoisan peoples of South Africa (1965) vervat.

Die vooroordele is deur vrees vir die onbekende aangevuur, veral na aanleiding van stories oor skipbreukelinge wat 'vyandiggesinde barbare' ontmoet het - aangevul met gepaste illustrasies en etnologiese beskrywings. Jan van Riebeeck, met 'n mandaat van die Vereenigde Oostindische Compagnie (VOC) om 'n verversingspos aan die Kaap in 1652 te vestig, het dus nie met 'n oop gemoed of objektiewe ingesteldheid gearriveer nie. Hy het reg van die begin af binne die onbetwisbare denkraamwerk van EuroChristelike meerderwaardigheid gefunksioneer. Dit, reken 
Reggie Nel (2016:61), was nie soseer oor sy witheid of ras nie, maar die bewese merkantilisme van die VOC. 'Die Kaapse koloniale besetting, en daarom ook die verdere besetting van Suider-Afrika, was ekonomies gedrewe' (Nel 2016:61).

Wat egter duidelik is ondanks Nel se nugtere waarneming, is dat Christen-ideoloë die Bybelverhaal van Noag gruwelik misbruik het. Laasgenoemde het 'n vloek oor Gam se nageslag (Kanaän) uitgespreek wat oënskynlik Afrikane was: 'Vervloek is Kanaän! 'n Nikswerd sal hy wees, in diens van sy broers' (Gen 9:25 - 1983-vertaling). Hierdie idees het saam die moreel-godsdienstige regverdiging vir die wrede slawepraktyk gevorm ten opsigte van hulle wat met 'n donker huid gebore is (vgl. Petersen 1979) - 'n kleur wat teologies met Satan en sonde, moreel-eties met die bose en esteties met afstootlikheid geassosieer is. 'n Kritak-publikasie (Aktiekomitee Zuidelijk Afrika 1982) bevind dat:

Hun huidskleur was zwart en de Europese cultuur verbond die kleur al eeuwenlang met duisternis, angst en het kwade, precies het tegengestelde dus van het christelijke licht en de christelijke blankheid. Hun huidskleur, die onuitwisbaar was, leverde het zichtbare bewijs dat zij zelf nooit konden veranderen, dat ze zich nooit konden ontwikkelen of iets anders konden zijn dan slaven en dienaars van hun blanke meesters. (bl. 34)

Aktiekomitee Zuidelijk Afrika (1982:34-40) verduidelik hoe inheemse mense aan krasse stereotipering onderworpe was: 'n minderwaardige mensesoort, onbeskaaf, slu, dom, barbaars, lui, immoreel, hiperseksueel, ensovoorts. Wie was en is die Khoikhoin en San dan werklik en het hulle enigsins 'n ware Godsbegrip gehad? Die $\neq$ Khomani-San van die Kalahari het in die afgelope dekade die term San verwerp en noem hulleself met trots Boesmans. Ek beskou dit as wisselterme afhangende van die situasie. Daar moet by hulle oorspronklike etniese identiteit begin word. Volgens onlangse taalkundige en biologiese toetse is bo alle twyfel bewys dat die eerste menslike wesens (homo sapiens) op ons kontinent ontwikkel het. Volgens Elsabé Brits (2006) is die Khoisan ongetwyfeld Suid-Afrika se eerste inheemse mense. In 'n artikel in Die Burger, berig Brits (2006) dat hulle 'n 'antieke stamboom' het soos vasgestel deur Peter Foster en Shuichi Matsumura wat menslike afstamming en genetiese patrone aan die Universiteit van Cambridge bestudeer. Hierdie argeoloë beklemtoon dat Afrika 'die Wieg van die mensdom' is, dit wil sê waar die eerste moderne mense ontstaan het. Op grond van toetse is verder bevind dat die Khoisan van Suider-Afrika die oudste DNS het wat tussen 60000 en 150000 jaar (of selfs meer) terugdateer (sien Figuur 1 en Figuur 2).

Argeoloë Deacon en Deacon (1999:129, 171) kom tot die volgende gevolgtrekking: 'We can confidently state that the ancestors of the Khoikhoi and San were an indigenous people that originated and diversified within southern Africa.' Schapera (1965:360-376) kom ook tot die slotsom dat hulle dieselfde oorsprong deel met spesiale verwysing na die ooreenkomste van hulle geloofsisteme.

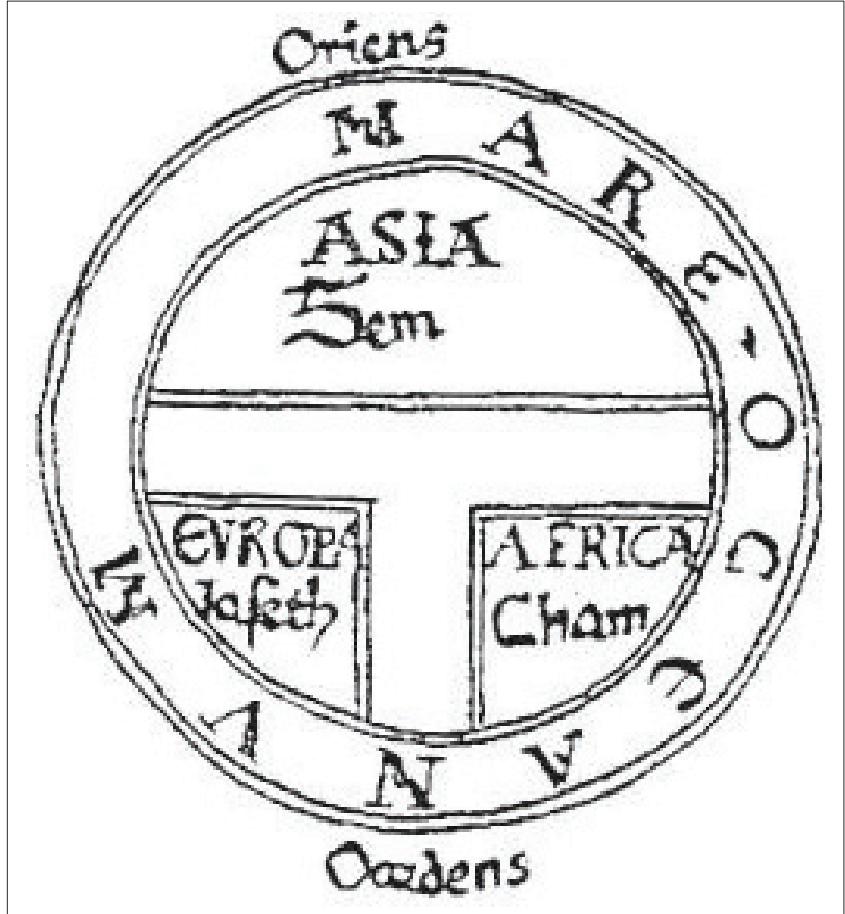

Bron: Bank, A., 1998, The proceedings of the Khoisan identities and cultural heritage conference, organised by the Institute for Historical Research, University of the Western Cape, held at the South African Museum, Cape Town, July 12-16, 1997

FIGUUR 1: 1500s-wêreldkaart.

\section{Evoluerende antieke geloof}

In Along edges (Krüger 1995:209-333) word die godsbewussynsgroei van die Boesmans oor millennia heen uiteengesit (Krüger verkies die benaming Boesmans). Die proses van 'hominisasie' (menswording), meen hy, het tot homo religiosus Africanus gelei. Saam met hulle liggaamlike ontwikkeling as eerste moderne mense, het ook die verstandelike en religieuse bewussyn gegroei (Krüger 1995). Historici soos Bredekamp (1982:5-12), en Elphick en Malherbe (1992:4-7), beskryf hulle twee pre-koloniale leefstyle wat sowat 2500 jaar gelede 'n aanvang geneem het, as jagterversamelaars en die latere herderslewe as veeboere. Hier is egter geen sprake van 'n strakke verdeling nie omdat albei ekonomiese lewenswyses soms afgewissel of selfs saam beoefen is. 'We can therefore speak of 'ecological cycles' from pastoralism to hunting and back to pastoralism' (Bredekamp 1982:5-10; Elphick \& Giliomee 1992:7).

Dit was die Duitse antropoloog, Leonard Schultze, wat eerste die samegestelde term Koïsan, gebruik het. Krüger (1995:222) verduidelik dat die term Khoisan '... captures not only the original unity, but also the complex process of gene flow and acculturation that continued between these two populations after some differentiation had already taken place'. Dit is dus 'n handige samestelling van die twee benaminge wat die eerste inheemse mense vir hulleself gebruik het, naamlik Khoikhoin [ménse-mense] en Sān [versamelaars]. Wat interessant is, is dat hulle godsbegrip ontwikkel en verander het binne die historiese konteks van die opeenvolgende leefwyses: by die San of Boesmans is die verbintenis tussen die Opperwese en die natuur daarom 


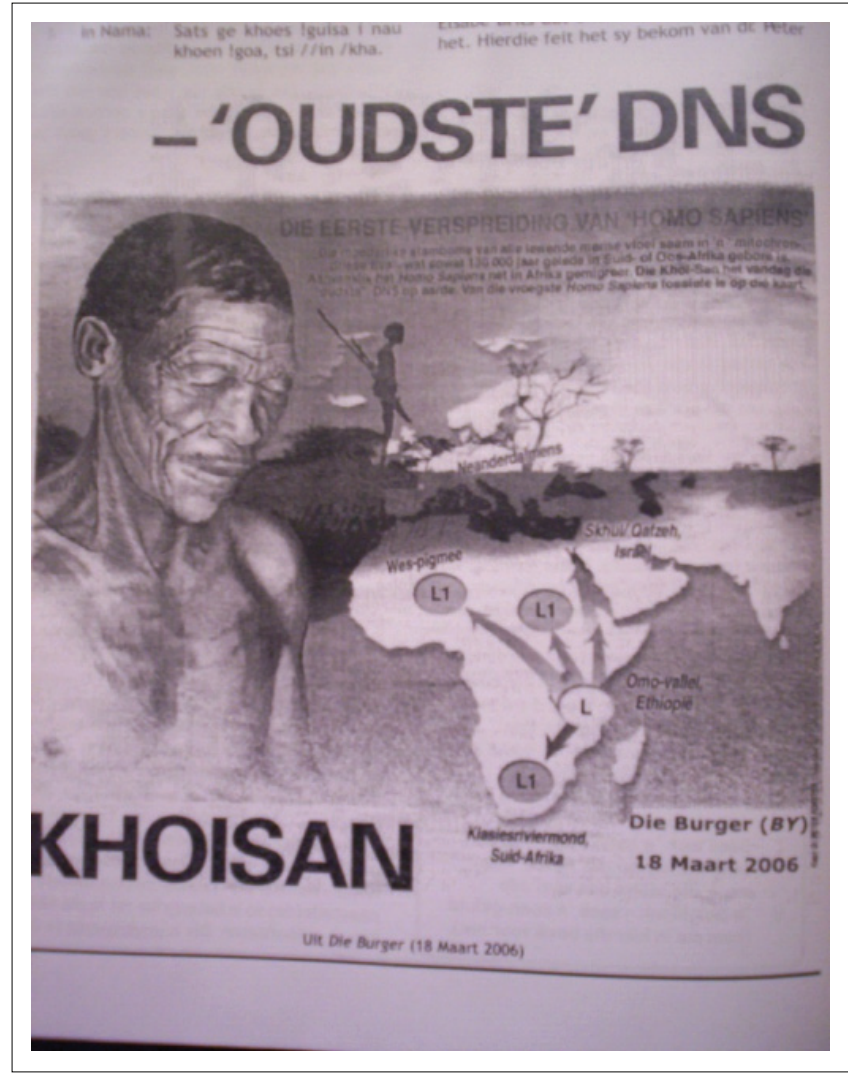

Bron: Deacon, J., 1998, Some views on rock paintings in the Cederberg, National Monuments Council, Cape Town

FIGUUR 2: Rotstekeninge in die Sederberge.

meer intiem en kan tereg van 'n ware ekologiese religie gepraat word. Die Khoikhoin se godsdiens het ook met die natuur te make gehad, maar hulle fokus was meer op hulle vee. Dat hierdie evoluering'n voorwetenskaplike gebeurtenis was, moet deeglik verdiskonteer word. Dit maak daarom kronologies sin om eers na die godsbegrip van die San te kyk, maar a priori moet die Euro-Christelike idee dat hulle die mantis aanbid het (vanwaar die term hottentotsgot sy oorsprong het), afgewys word (Deacon 1998:49). Vir hulle was God, volgens die verskillende streektale N!adima, Hishe, Thora, !Khwa, /Kaggen, Huwe en / A'an. Verwarring het moontlik by waarnemers ontstaan omdat die San dieselfde naam (/kaggen) vir die mantis gebruik het as die streekgebonde Godsnaam - net met 'n hoofletter (/Kaggen) (Boezak 2016:100-102).

Die vroegste vaslegging van hulle godsgeloof vind ons in petrogliewe en gravures. Primêr praat ons egter van sakrale tekste eerder as blote rotskuns of Boesmantekeninge. Volgens Deacon (1999:55; cf. Krüger 1995:326) is hierdie kultuurerfenis '... a remarkably resilient religious art form that demonstrates more eloquently than any written words the full power and sophistication of the San belief system that lasted for thousands of years in southern Africa'. Korrekte interpretasies daarvan openbaar hulle antieke godsdienstige gewoontes waarin die genesing van siekes en reënmaak-rituele ' $n$ kritieke rol gespeel het.

Ouzman (2009:101-112) noem dat veral geloofsgenesing in die vorm van petrogliewe uitgebeeld was. Vir die San is die

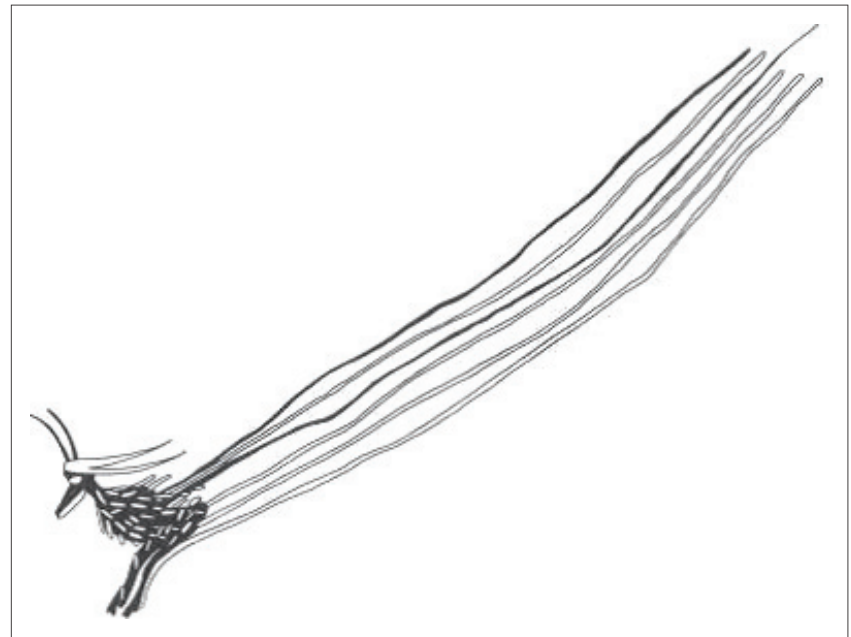

Bron: Lewis-Williams 1999

FIGUUR 3: Rotstekening in die Drakensberge, Kwa-Zulu Natal. Die sjamaan se gees reik uit na die krag van God se Gees.

dans van heling die kern en fokus van hulle godsdiens. Daardeur verbind hulle hulself aan die n/um [krag] van God wat aan almal beskikbaar is - mans sowel as vroue. Die hoofdoel daarvan is om die bose te verdryf en die siekes te genees. Krüger (1995:316-322) beskryf die helingsdans van die !Kung as tiperend van wat algemeen voorkom. Gewoonlik vind dit by volmaan plaas, terwyl 'n vuur die hele nag brand. Die vroue en kinders sit in 'n kring, klap hande en sing, terwyl die mans ritmies dans. Hulle sweet dan baie en sommige se neuse bloei selfs.

Hulle liedere van genesing handel oor die mag van natuurkragte soos die reën, die eland en die waterbuffel. Die sjamane [voorgangers of bemiddelaars] word deur die goddelike $n / u m$ in besit geneem en bereik so ' $n$ ander staat van bewussyn (!kia). Hulle trek dan die siekte van die lydendes in hulle eie liggame en werp dit in die duister waar die bedrieër-godheid en die bose geeste van dooies wag. Dan word kole in die hare gevryf totdat hulle eie geeste hulle liggame verlaat en met die bedrieër-godheid - wat die ellende veroorsaak het - worstel om die boosheid (siekte) terug te neem. Die sjamaan val dan in 'n diepe beswyming, 'n skyndood, waarna die dansers hom of haar herstel sodat sy of haar gees kan terugkeer. Ook wanneer die clan se bestaan deur 'n langdurige droogte bedreig word, 'maak' die sjamaan reën deur die Bringer van voorspoed te nader (Boezak 2016:84-88). Dis verblydend dat hierdie antieke sakrale danse van genesing en reënmaak vandag steeds deur die $¥$ Khomani San van die Kalahari beoefen word (sien Figuur 3).

Dis opvallend dat die eerste sendeling vir die Khoikhoin, die Hernhutter Georg Schmidt (1981), in sy Das Tagebuch und die Briefe von Georg Schmidt, dem ersten Missionar in Südafrikal Dagboek en briewe van Georg Schmidt, eerste sendeling in SuidAfrika (1737-1744), noem dat die Overbergse Hessekwa wat hy bedien het van 'Tikqua' gepraat het. Bredekamp (1988: 20-31) is van mening dat die sendeling se mededelinge aan hulle onbevredigend was: eerstens, as gevolg van die vreemdheid van hulle taal wat begrip bemoeilik het; en 
tweedens, omdat hy nie eintlik belang gestel het om by die bestaande Khoigeloof aan te sluit nie. Graaf von Zinzendorf, vir wie hy verteenwoordig het, het immers geglo dat alle volke wel 'n godsbewussyn het, maar hierdie 'heidense geloof in Tikqua' was nie aanvaarbaar nie. Bredekamp (1988) voer aan dat:

Die Overbergse Khoikhoi had immers 'n eie mitologiese verstaan van die oorsaak van die kwaad in die wêreld en hoe dit oorwin kon word. Schmidt was egter so begeester met sy eie verstaan van die bonatuurlike werklikheid en Zinzendorf se christosentriese verstaan van die sosiale werklikheid, dat ... hulle verstaan van die kosmiese nie veel indruk op hom kon maak nie. (bl. 23)

Met ander woorde die Pauliniese geloofsinkulturasie as paradigma het by Schmidt ontbreek (vgl. 1 Kor 9:20-23).

Theophilus Hahn was die seun van 'n sendeling en het tussen Suid-Afrika se Namamense grootgeword. Hy het 'n oergebed van hulle opgeteken wat ons binne die kader van die evoluerende godsbegrip van die Khoikhoin moet verstaan. Dis daarom vanselfsprekend 'n herdersgebed (Hahn 1881:58-59):

$\begin{array}{ll}\text { Tsui | I Goatse! } & \text { U, o Tsui I I Goa! } \\ \text { Abo Itse, } & \text { Vader van ons voorouers } \\ \text { Sida Itse! } & \text { Onse Vader! } \\ \text { I Nanuba I avire } & \text { Laat stroom die reënwolk } \\ \text { En xuna ûire } & \text { Laat ons kudde leef } \\ \text { Eda sida ûire; } & \text { Laat ons ook leef, asseblief; } \\ \text { †Khabatu gum goroö } & \text { Want ek is so swak } \\ \text { I gäs xao, } & \text { Van dors, } \\ \text { !as xao... } & \text { Van honger... } \\ \text { Eta xurina amre. } & \text { Laat my veldvrugte eet. } \\ \text { Sats gum xave sida itsao, } & \text { Is U dan nie onse Vader, } \\ \text { Abo itsao } & \text { Vader van ons voorouers } \\ \text { Tsui I I Goatse? } & \text { U, Tsui I I Goa? } \\ \text { Eda sida gangantsire } & \text { Dat ons U mag loof } \\ \text { Eda sida | | khava I khaitsire } & \text { Dat ons U kan eer } \\ \text { Abo itse, } & \text { U, Vader van ons voorouers } \\ \text { Sida !khutse - } & \text { U, onse Heer - } \\ \text { Tsui I I Goatse! } & \text { U, Tsui I I Goa! }\end{array}$

Vir die Khoi-veeboere was die jaarlikse reënmaak-seremonie - die guri $\neq a b$ - die belangrikste godsdienstige fees op hulle kalender. Schapera (1965:317-389) vertel in detail van hierdie ritueel en op welke tye en geleenthede verskillende gebede gebruik is. By die guri $\neq a b$ is 'n vroulike dier soos byvoorbeeld 'n ooi geslag. Dit moes dragtig wees as 'n teken van vrugbaarheid. Die oudstes stel dan vas wanneer die somerreëns sou begin en reël die fees naby 'n stroom. Al die families in die kraal kom bymekaar en bring melk wat saam met die dragtige ooi se vet sowel as die inhoud van die baarmoeder verbrand word. Terwyl die rookwolk opstyg, roep almal Tsui- //Goa aan en bid om 'n goeie jaar vir reën, voedsel en weivelde. Die donker rook vergestalt die hoop op wolke wat swanger moes raak van reën (vgl, beskrywing van die reënseremonie deur Hoernlé 1985:75-76). Hoewel dit 'n voor-christelike gebed was, is die opvallende ooreenkomste met die Onse Vader-gebed van Jesus (Matt 6:9-13) merkwaardig. Korter weergawes van die oergebed en ook lofliedere is by ander geleenthede gebruik, byvoorbeeld soggens met die verskyning van die Plejades (Sewe-ster) in die ooste, waar God woon.

Uit bogenoemde is dit duidelik dat vir die jagter-versamelaars sowel as vee-eienaars God die Beskermer is wat oor alle lewende wesens besorg is. Lewe in die vorm van gesondheid, reën en weiding is 'n kosbare goddelike gawe, maar daardie goeie werk word deur die Bose weerstaan.

\section{Die oerstryd}

Die Khoisan, wat in 'n liefdevolle Skepper en regverdige Beskermer geglo het, het geweier om die kwade aan God toe te dig (Schapera 1965:172-201). Hier vind ons reeds vroeë spore van die bekende teodisee-problematiek. Daarom is verskynsels soos droogtes, sons- en maansverduistering, donderweer, komete, dwarrelwinde, verskietende sterre, siektes en die dood aan 'n persoonlike bose mag wat nie onderskat moes word nie, toegeskryf. Sulke verskynsels druis in teen die ordelike skepping van God. Dit kan dus nie van die Opperwese afkomstig wees nie, maar eerder van 'n mindere godheid, ! Gauna of //Gauwa (Schapera 1965:172-201).

Die Boesmans van die Kalahari glo dat die goeie Skepper, !Khwa, en die bose !Gauna in 'n hewige stryd teen mekaar gewikkel was; So ook die Khoikhoin (vgl. Yahwe en die farao). Tsui- //Goa was in 'n oerstryd met / / Gauna gewikkel. Hierdie mitologiese stryd het 'n lang tyd geduur, voordat die Bose ' $n$ finale slag toegedien is. Die Skepper het uiteindelik oorwin, maar is in daardie oergeveg verwond. Daarom beteken Tsui- //Goa letterlik 'gewonde knie', afgelei van die woordstam //gau [om te vernietig]; //gaurà [sleg of waardeloos], en //gaua [vernieling en uitwissing]. Wanneer die weerlig byvoorbeeld iemand doodslaan, word gesê: '//Gaua het haar geneem' (Boezak 2016:106-110; Krüger 1995:300-301; Schapera 1965:377).

Hierdie is die kern van die Khoisan se geëvolueerde godsopvatting en ekologiese spiritualiteit. Hoewel die kwade steeds in ons midde is, beskerm Tsui-//Goa as verwonde Haar of Sy kinders en is daarom daagliks empaties betrokke by hulle stryd teen lyding. Hier is geen sprake van 'n theos apátheia nie. Die gewonde Een staan nie afsydig wanneer siekte, ongeluk, depressie of ellende ons teister nie, Hy het, trouens, meegevoel met ons wanneer die lewe óns verwond. As die Een wat self ly, weet God wat dit is om pyn en vernedering, maar ook oorwinning te smaak. Daarom kan met oorgawe in die kraal gebid word:

\section{U, o Tsui- //Goa! \\ Laat ons kudde leef}

Laat ons ook leef, asseblief

Want ons is swak van honger en dors. 


\section{Die gewonde God vandag}

Theuns Eloff ontleed in sy boek Wat nou Suid-Afrika? (2015) op 'n gebalanseerde wyse die positiewe sowel as kommerwekkende aspekte van ons samelewing aan die hand van harde feite, nagevorsde gegewens en bevindinge. Dis skrikwekkend om te verneem dat volgens '... statistieke vir 2015 beklee Suid-Afrika die vierde hoogste posisie op die wêreld se misdaadindeks' (Eloff 2015:131). Daarby kom die onaanvaarbare hoë vlakke van werkloosheid onder jongmense, kroniese gemeenskapsarmoede, korrupsie, wrede plaasaanvalle, 'n mislukkende openbare gesondheidsisteem, 'n sukkelende onderwysstelsel, en die groterwordende kloof tussen rykes en armes.

Soos aangetoon, het swart teoloë gestel dat die bevrydende God binne situasies van onreg en ontmensliking 'n 'voorkeurreg' ten opsigte van die lydendes uitoefen. Natuurlik is dit moontlik dat so 'n godsbeskouing vir eie politieke gewin gekaap kan word. So is die onlangse uitspraak van president Jacob Zuma dat 'God aan die kant van die ANC' is, gewoon banaal (Dawie 2017:9). 'n Korrekte posisionering van die bevrydende God vind ons in artikel 4 van die Verenigende Gereformeerde Kerk van Suid-Afrika (VGKSA) se Belydenis van Belhar. Beukes (2016) reken dat die:
... afgevaardigdes van die NGSK Sinode van 1982 het die onderdrukking en ongeregtigheid van hierdie apartheidsbeleid aan hulle lywe gevoel ... (bl. 48)
Die NGSK bevestig verder ook in artikel 4 van die Belydenis hul geloof en glo dat God in 'n wêreld vol onreg en vyandskap op 'n besondere wyse die God van die noodlydende, die arme en die verontregte is en dat Hy sy kerk roep om Hom hierin na te volg. Die kerk moet daarom mense in enige vorm van lyding en nood bystaan. (bl. 49)

Dis later deur die nuutgestigte VGKSA as belydenisskrif in 1994 aanvaar. Let wel: die belydenisskrif gebruik nie die term alleenlik nie, maar op 'n besondere wyse die God van die noodlydende. Dis daarom besonder jammer dat die VGKSA haar eie belydenis se reikwydte nie begryp nie en steeds lesbies, biseksueel, gay, transgender, queer, interseksueel en aseksueel (LBGTQI+), gemarginaliseerdes en miskendes uit die Kerk wat veronderstel is om God se omgee-gemeenskap te wees, sluit. Na 23 jaar van demokrasie noop die via dolorosa van miljoene dat steeds die bevrydende boodskap van die gewonde God gehoor moet word.

Tsui- //Goa emuleer mankheid om empaties by verbryseldesvan-hart betrokke te wees, ongeag of hulle in plakkerskampe of Sandton woon. Hoe veelseggend en ryk aan simboliek is dit nie dat Sanjagters mank agter 'n gewonde dier aanloop nie? (Krüger 1995:306).

\section{Slotwoord}

Die era waarin swart teologie in Suid-Afrika gedy het, was gedurende die apartheidsjare. Dit was ook die tydperk waar die teodisee-vraagstuk gereeld in Afrikaanse, Bruin protespoësie voorgekom het, veral in die werke van Adam
Small wat briljant die patos en patois van straatpredikers weergee. In hierdie artikel word nie soseer swart teoloë se sistematies-teologiese insigte ten opsigte van die vraagstuk onder die loep geneem nie, maar spesifiek hulle prediking, met ander woorde hoe hulle bevrydingsteologie binne die intieme ruimte van die gemeente tot sy reg gekom het. Die uitsondering hier is Mofokeng wat in kritiese gesprek met Moltmann aangaande sy theologia crucis [teologie van die kruis] tree. Laasgenoemde het reeds in die sestigerjare sy begrip van 'the believing hope' ontwikkel wat uit die lyding van Christus spruit, die Gekruisigde (Moltmann 1967):

It is only infollowing the Christ, who was raised from suffering, guilt and death, from a god-forsaken death and from the grave that it gains an open prospect in which there is nothing more to oppress us, a view of the realm of freedom and of joy. (pp. 19-20)

Volgens my is die apeks van Moltmann (1967:329-338) se teologie van hoop sy oproep tot Christene om die samelewing te humaniseer. Die eskatologiese hoop op geregtigheid moet reeds nou verwerklik word. Die wêreld, beklemtoon hy (Moltmann 1967), is nie voltooid nie, maar op sy weg na 'n toekoms waarin die waarheid, geregtigheid en vrede ons beloof is:

The glory of self-realization and the misery of self-estrangement alike arise from hopelessness in a world of lost horizons. To disclose to it the horizon of the future of the crucified Christ is the task of the Christian Church. (p. 338)

Vanselfsprekend kon swart teoloë in Suid-Afrika daarby aanklank vind - veral met betrekking tot die vermensliking van die samelewing - maar, vanweë die radikaal verskillende sosio-politieke kontekste, veel meer by hulle eweknieë soos Gayraud Wilmore en James Cone in die VSA. Die gepubliseerde doktorale proefskrif van Boesak, Farewell to innocence (1976), weerspieël duidelik daardie wedersydse beïnvloeding. Dis te verstane dat na 1994 die herposionering van die Kerk ten opsigte van haar profeties-kritiese rol teenoor 'n demokraties-verkose regering 'n geweldige uitdaging was. Uit sy post-apartheid preekbundels is egter dieselfde deurlopende bevrydingstema - wel met nuwe aksente - by Boesak te merk. So stel hy (Boesak 2004) byvoorbeeld in sy boek The fire within:

In South Africa apartheid is over, but apartheid is everywhere ... The power relationships have hardly shifted, and the grip of the old, moneyed establishment on almost every facet of life is fearsome. Racism, even vehemently denied, continues to plague us, and fathers bitter injustice in our courts. HIV / Aids is a raging beast that is seeking to destroy the future of our nation, and our politicians play word games. The gap between the new black elite and the poor black masses is as wide as any gap that ever existed, only more painful. (p. 69)

'n Jaar later verskyn sy preekbundel wat die Bybelverhale van vroue - agtergestel binne 'n erg-patriargale sisteem opvallend vooropstel. In Die vlug van Gods verbeelding (Boesak 2005:111-134) word die onderskikte status van die Samaritaanse vrou by die put hermeneuties van die 'onderkant' hanteer, dog op 'n duidelik homiletiese manier. Jesus se openlike gesprek met haar was 'n verbreking van 
verskeie taboes te midde van die langdurige vyandskap tussen die Jode en Samaritane. Boonop was haar reputasie as 'n 'los vrou' veronderstel om 'n verdere beletsel te wees. Die skrywer (Boesak 2005) sê egter:

Hy wil haar iets anders bied as net putwater wat die liggaamlike dors les. Waar Hy oor praat is lewende water wat fundamentele verandering bring op alle vlakke van die menslike bestaan en waarvan die gevolge nie net tot hierdie lewe of die klein kring van haar bestaan beperk sal wees nie. (bl. 119)

Dan keer Boesak (2005:123) nogmaals terug na die kerngeloofsuitspraak binne Bevrydingsteologie: 'Die God van Hagar en Hanna en Maria ... Die beskermer van die swakkes en die armes, die uitgebuitendes en die vertraptes, die ongeteldes ...' Anlené Taljaard (2016) som Boesak se bevrydingsprediking as volg op:

The Word that he preached, in obedience to God - truly nourished, illuminated, persuaded and liberated many people towards life-giving practices. In particular, it nourishes those who suffer, it illuminates the minds from false beliefs, it persuades the heart to love the neighbour with non-violent action, it liberates societies from unaccountable greed and it global citizens for a conscious living that fosters life-giving practices. (p. 130 [kursief Taljaard])

Ek poneer dat binne die oeuvre van stemme wat moreleetiese imperatiewe aangaande 'n medelydende Opperwese oproep, die oeroue, sinryke, geëvolueerde beeld van die gewonde God vandag simbolies die situasies van die hopeloses en hulpeloses die raakste aanspreek. In God's wrathful children (Boesak 1995) kom ek tot die volgende slotsom:

The Khoi-Khoi thus believe in a suffering God amidst the human reality of the cycle of evil, sickness, and death, rather than a triumphant Omnipotent. The final battle in which //Gaunab will be finally destroyed is yet to come. The confession that God actually bears a scar vindicates the Supreme Being, who now suffers in human history but will triumph over evil ultimately. (pp. 222-223)

\section{Erkenning \\ Mededingende belange}

Die outeur verklaar dat sy geen finansiële of persoonlike verbintenis het met enige party wat haar nadelig kon beïnvloed het in die skryf van hierdie artikel nie.

\section{Literatuurverwysings}

Aktiekomitee Zuidelijk Afrika, 1982, De wereld in zwart-wit: De geschiedenis van het racisme, KRITAK publikatie, Leuven.

Bank, A., 1998, The proceedings of the Khoisan identities and cultural heritage conference, organised by the Institute for Historical Research, University of the Western Cape, Held at the South African Museum, Cape Town, July 12-16, 1997.

Beukes, J.W., 2016, 'Die Belydenis van Belhar: belydenis van 'n kerk weerklink wêreldwyd', in W.A.M. Carstens \& M. le Cordeur (reds.), Ons kom van vêr: bydraes oor bruin Afrikaanssprekendes se rol in die ontwikkeling van Afrikaans, pp. 39-56, Naledi, Kaapstad.

Boesak, A.A., 1976, Farewell to innocence: A social-ethical study on Black theology and Black power, J.H. Kok, Kampen.

Boesak, A.A., 1979, Die vinger van God: Preke oor geloof en politiek, Ravan Press, Johannesburg.

Boesak, A.A., 1984a, Black and reformed, Orbis Books, New York.
Boesak, A.A., 1984b, Kiest dan heden, wie gij dienen zult: Preken, J.H. Kok, Kampen.

Boesak, A.A., 2004, The fire within: Sermons from the edge of exile, New World Foundation, Cape Town.

Boesak, A.A., 2005, Die vlug van Gods verbeelding: Bybelverhale van die onderkant, Sun Press, Stellenbosch.

Boesak, W., 1995, God's wrathful children: Political oppression \& Christian ethics, William Eerdmans Publishing Company, Grand Rapids, Michigan.

Boezak, W., 2016, Só glo ons: die Khoisan van Suid-Afrika, Bidvest Data, Kaapstad

Boonzaier, E., Malherbe, C., Berens, P. \& Smith, A., 2000, The Cape herders: A history of the Khoikhoi of Southern Africa, David Philip, Cape Town.

Bredekamp, H.C., 1982, Van veeverskaffers tot veewagters:'n Historiese ondersoek no betrekkinge tussen die Khoikhoi en Europeërs aan die Kaap, 1652-1679, Die WesKaaplandse Instituut vir Historiese Navorsing, Bellville.

Bredekamp, H.C., 1986, 'From fragile independence to permanent subservience (1488-1713)', in T. Cameron \& S. Spies (eds.), An illustrated history of South Africa, pp. 102-105, Jonathan Ball, Johannesburg.

Bredekamp, H.C., 1988, 'Georg Schmidt se poging tot transformasie van 'n Overbergse Khoikhoi-gemeenskap', Kronos: Southern African Histories 1(41), 20-31.

Brits, E., 2006, 'Uit die skoot van Afrika: Khoisan - oudste DNS', Die Burger Bylae, 18 Maart, bl. 16.

Bundy, C., 1988, The rise and fall of the South African peasantry, J. Currey Publications, Cape Town.

Buthelezi, M., 1977, 'Service to the down-trodden', Pro Veritate, 8 January, p. 8.

Buthelezi, M., 1979, 'Violence and the cross in South Africa today', Journal of Theology in Southern Africa 29, 51-57.

Carstens, W.A.M. \& Le Cordeur, M. (reds.), 2016, Ons kom van vêr: bydraes oor bruin Afrikaanssprekendes se rol in die ontwikkeling van Afrikaans, Naledi, Kaapstad.

Dawie, 2017, 'Dink Zuma God is 'n ANC-lid?', Die Burger, 28 Januarie, bl. 9.

Deacon, H. \& Deacon, J., 1999, Human beginnings in South Africa: Uncovering the secrets of the Stone Age, David Philip, Cape Town.

Deacon, J., 1998, Some views on rock paintings in the Cederberg, National Monuments Council, Cape Town.

Durand, J.J.F., 1976, Die lewende God, NG Kerkuitgewers, Pretoria.

Eloff, T., 2015, Wat nou, Suid-Afrika?, Tafelberg, Kaapstad.

Elphick, R. \& Giliomee, H. (eds.), 1992, The shaping of South African society: 16521840, Maskew Miller Longman, London.

Elphick, R. \& Malherbe, V.,1992, 'The Khoisan to 1828 ', in R. Elphick \& H. Giliomee, (eds.), The shaping of South African society: 1652-1840, pp. 3-65, Maskew Miller Longman, London.

February, V., 1981, Mind your colour: the 'Coloured' stereotype in South African literature, Kegan Paul, London.

Goba, B., 1973, 'Corporative personality in ancient Israel and Africa', in B. Moore (ed.) Black theology: the South African voice, pp. 65-73, Ten Have, Baarn.

Goba, 1979, 'The role of the black church in the process of healing human brokenness', Journal of Theology in Southern Africa 28, 7-13.

Goba, B., 1982, 'Theology and existential commitment', Journal of Theology in Southern Africa 41, 50-54.

Hahn, T., 1881 Tsuni-Goam: the Supreme Being of the Khoi-khoi, (heruitgawe 2000), Trübner, London.

Hoernlé, W., 1985, The social organization of the Nama and other essays, Witwatersrand University Press, Johannesburg

Kameeta, Z., 1976, 'The cross in the world, Pro Veritate, 14 July, p. 14.

Kieskamp, A., 1998, 'The Khoekhoe in Van Riebeeck's official accounts of a period: 1652-1662', in A. Bank (ed.), The proceedings of the Khoisan identities and cultural heritage conference, Institute for Historical Research, University of the Western Cape, Cape Town, July 12-16, 1997, pp. 165-171.

Krüger, J.S., 1995, Along edges: Religion in South Africa - Bushman, Christian, Buddhist, UNISA, Pretoria.

Lewis-Williams, D.J, 1999, Images of power: understanding San rock art, Southern Book Publishers, Johannesburg.

Maimela, S.S., 1982, 'Towards a theology of humanization', Journal of Theology in Southern Africa 41, 58-65.

Malherbe, F.E.J., 1948, Wending en inkeer: 'n Beskouing oor die nuwere Afrikaanse letterkunde, Nasionale Pers, Kaapstad.

Marks, S., 1972, 'Khoisan resistance to the Dutch in the seventeenth and eighteenth centuries', Journal of African history 13(1), 55-80.

Mofokeng, T., 1983, The crucified among the crossbearers: Towards a black Christology, J.H. Kok, Kampen.

Moltmann, J., 1967, Theology of hope, SCM Press, Alva.

Moltmann, J., 1973, Der Gekreuzigte Gott: das Kreuz Christi als Grund und Kritik christlicher Theologie, Chr. Kaizer, München.

Moore, B. (ed.), 1975, Black theology: the South African voice, Ten Have, Baarn.

Nel, R., 2016, 'Genote, gelowig en geskei', in W.A.M. Carstens \& M. Le Cordeur (reds.), Ons kom van vêr: bydraes oor bruin Afrikaanssprekendes se rol in die ontwikkeling van Afrikaans, pp. 57-71, Naledi, Kaapstad. 
Ouzman, S, 2009, 'The Magical Arts of a Raider Nation' in G. Bundell (ed.), South African Archaeological Society, pp. 101-112, SA Arch Society, Johannesburg. (Goodwin Series, 9).

Petersen, S.V., 1979, Alleenstryd: ' $n$ Kern uit sy verse, Tafelberg Uitgewers, Kaapstad.

Schapera, I., 1965, The Khoisan peoples of South Africa: Bushmen and Hottentots, George Routledge \& Sons, London.

Schmidt, G., 1981, Das Tagebuch und die Briefe von Georg Schmidt, dem ersten Missionar in Südafrika/Dagboek en briewe van Georg Schmidt, eerste sendeling in Suid-Afrika (1737-1744), gered. en vert. H.C. Bredekamp \& J.L. Hattingh, Instituut vir Historiese Navorsing Publikasies, UWK, Belville.

Small, A., 1961, Die eerste steen?, HAUM, Kaapstad/Pretoria.

Small, A., 1974, Kitaar my kruis, HAUM, Kaapstad.
Small, A., 2011, Kô lat ons sing: 'n Keur uit Adam Small se gedigte, saamst. S. van Wyk, Kwela Boeke, Kaapstad.

Taljaard, A., 2016, 'Unashamed Evangelical? - the poetic-preached word of salvation that nourishes, illuminates, persuades and liberates our full humanity', in C.D. Flaendorp, N.C. Philander \& M.A. Plaatjies van Huffel (eds.), Festschrift in honour of Allan Boesak: a life in Black liberation theology, pp. 119-132, Sun MeDIA of Allan Boesak.
Stellenbosch.

Tutu, D.M., 1982, The voice of one crying in the wilderness, A.R. Mowbray \& Co., London.

Van Zyl, A.H., 1975, Gods Woord in mensetaal, Butterworth, Durban.

West, C., 1982, Prophesy deliverance! An Afro-American revolutionary Christianity, Beacon Press, Philadelphia. 